\author{
E-ISSN: 2469-6501 \\ VOL: 7, ISSUE: 10 \\ October/2021 \\ DOI: http://dx.doi.org/10.33642/ijbass.v7n10p1 \\ https://creativecommons.org/licenses/by/4.0/
}

\title{
The Effect of Institutional Ownership and Audit Committee on Audit Quality with Financial Distress as Moderation: On Manufacturing Sector Companies Listed on The Indonesia Stock Exchange Period 2016-2020
}

\author{
Jombrik $^{1}$, Vika Alifta Tamami ${ }^{2}$ \\ University of Darma Persada \\ Jl. South Malacca Park No.8, RW.6, Pondok Kelapa. \\ Duren Sawit, East Jakarta, 13450 \\ Email; brikradha@yahoo.co.id and aliftafika@gmail.com \\ Indonesia
}

\section{ABSTRACT}

This study aims to analyze the effect of institutional ownership and audit committee on audit quality with financial difficulties as a moderation. This research was conducted on Manufacturing Companies in the Consumer and Industrial Goods Sector Listed on the Indonesia Stock Exchange for 2016-2020. The quantitative research method uses secondary data, namely the company's annual report that is the object of research. Analysis of the data used is logistic regression analysis. The results show that the direction of the influence of the institutional ownership variable on audit quality is positive, where institutional ownership has a significant effect on audit quality. Likewise, the direction of the impact of the audit committee on audit quality is positive but does not significantly affect audit quality. The results of the moderation show that Financial Distress can moderate institutional ownership in influencing audit quality. In contrast, after being moderated with the financial distress variable, the audit committee has a negative and significant direction, which means it can moderate the audit committee in influencing audit quality but in the opposite direction.

\section{Keywords: Audit Quality, Institutional Ownership, Audit Committee, Financial Distress.}

\section{Introduction}

The audit is one way to find out the company's achievements at a specific time. For companies that have gone public, auditing is an obligation that the company must carry out. In Indonesia, following Rule Number III-D issued by the Board of Directors of the Indonesia Stock Exchange (IDX), every company that sells its shares on the Indonesia Stock Exchange (IDX) must publish the company's financial statements that have been audited by an independent auditor.

According to Agoes (2017), an audit is an examination carried out critically and systematically, by an independent party, on financial statements prepared by management, along with accounting records and supporting evidence, to provide an opinion on the fairness of the report. Therefore, the financial statements must be presented truthfully through an audit conducted by the auditor so that the truth can be trusted. This great trust from users of audited financial statements and other services provided by public accountants ultimately requires auditors to pay attention to the quality of the audits produced (Wardana \& Ariyanto, 2016).

Financial reporting is one of the responsibilities of management. At least the company's financial statements must meet two characteristics, namely relevant and reliable, to provide a reflection and data on the company's prospects needed (Lestari et al., 2019). Financial statements are said to be relevant when the financial statements can help users of the report assess business activities. In contrast, financial statements are reliable when the information contained in the financial statements is guaranteed not to be materially misstated (Lestari et al., 2019).
Several factors are considered to influence audit quality, one of which is Corporate Governance. Corporate governance is essential in a company because a company must have good governance so that the company continues to run properly and avoid financial distress conditions. Financial distress is when the company is unable to pay its obligations, which will increase costs so that the company cannot maintain its existence. The company's failure to maintain its presence is caused by two main factors, namely internal factors, and external factors. External factors arise from outside the corporation, which can be related to operations or even macroeconomic aspects, while internal factors are aspects that arise from the internal of the corporation. The internal element that causes financial difficulties experienced by companies is usually the inability of management to manage a business and corporate finances. Inefficient management causes ongoing losses, which ultimately impact the company's obligations that cannot be fulfilled or cannot be paid so that the company experiences financial difficulties or financial distress (Kristanti, 2019).

Various factors are suspected to influence audit quality. The first is institutional ownership. According to Pasaribu (2016), institutional ownership is the percentage of shares owned by institutions. Institutional ownership is a tool that can be used to reduce conflicts of interest. Tanujaya \& Susiana (2021) found that institutional ownership affected audit quality, research by Johnbest \& Ologhodo (2020) found that institutional ownership had no significant impact on audit quality. The second factor is the audit committee. In OJK Regulation 55/2015, Article 1 paragraph (1) of the audit committee is a committee formed by and responsible to the 


\author{
E-ISSN: 2469-6501 \\ VOL: 7, ISSUE: 10 \\ October/202 1 \\ DOI: http://dx.doi.org/10.33642/ijbass.v7n10p1

board of commissioners in helping carry out the duties and functions of the board of commissioners. The third factor is financial distress which in this study is a moderating variable. Pertiwi, Hasan \& Hardi (2016) found that the audit committee affected audit quality, and the consequences of Silviyani, Suratman \& Erlangga's (2020) research found that the audit committee had an effective audit committee had no significant impact on audit quality.

\section{Literature Review and Hypotheses}

\section{Audit}

According to Mulyadi (2016), an audit is a systematic process to obtain and evaluate evidence objectively regarding statements about economic activities and events, determine the level of conformity between these statements and predetermined criteria, and deliver the results. According to Arens \& Beasley (2010:4) in Setiawan (2013), auditing is the collection and assessment of evidence regarding information to determine and report the level of conformity between the data and the established criteria. Viewed from the perspective of the public accounting profession, an audit is an objective examination of the financial statements of a company or other organization to determine whether the financial statements present fairly, in all material respects, the financial position and results of operations of the company or organization. Reviewing compliance with laws and regulations related to the activities of the Issuer or Public Company.

\section{Audit Quality}

According to Arens (2015), audit quality is how an auditor detects material misstatements in the financial statements. The detection aspect is a reflection of the auditor's competence, while reporting is a reflection of the auditor's integrity, especially the auditor's independence.

Audit quality is separated into the actual quality and perceived quality. Conditions that indicate a decrease in risk of material misstatement in financial reporting are called real quality. On the other hand, the level of trust of users of financial information on auditor efficiency in reducing material misstatements in financial reporting is reached through perceived quality (Husnin, Nawawi, \& Salin, 2016).

\section{Audit Committee}

According to Verawati and Wirakusuma (2016), the audit committee is one component of corporate governance that plays an essential role in the financial reporting process by supervising independent auditors' work in the financial reporting process and assisting the duties of the board of commissioners. The audit committee consists of three people, two experts who are not employees concerned, and at least one member of the board of commissioners who is directly responsible to the supervisory board or commissioner who is independent in carrying out their duties and reporting (Amelia, 2016).
According to the Financial Services Authority Regulation Number 55/POJK.04/2015, the audit committee is a committee responsible to the Board of Commissioners in assisting in carrying out the duties and functions of the Board of Commissioners. Issuers or Public Companies are required to have an Audit Committee. Members of the Audit Committee are appointed and dismissed by the Board of Commissioners. The Audit Committee consists of at least 3 (three) members who come from Independent Commissioners and Parties from outside the Issuer or Public Company.

\section{Ownership Structure}

The shares ownership structure is the proportion of management ownership, institutional, and public ownership, and the ownership structure is a mechanism to reduce conflict between management and shareholders. Yuniati (2016), Institutional Ownership is the percentage of shares owned by institutions. Institutional ownership is a tool that can be used to reduce conflicts of interest. Institutional ownership is the amount of share ownership by institutions (government, foreign companies, financial institutions such as insurance, banks, and pension funds) (Pasaribu, 2016). Institutional ownership has an essential meaning in monitoring management because institutional ownership will encourage more optimal supervision. Supervision carried out by institutional investors will ensure the prosperity of shareholders.

\section{Financial Distress}

Kristanti (2019) states that financial difficulties are situations where a company can no longer pay its obligations on its payment schedule. Another concern is when the company is indicated that it will not pay its debts which is reflected in its cash flow projections. Companies that experience financial distress are restructuring, intending to avoid default, or as a reason to anticipate default on their debt contracts. Default is when the company cannot make payments on obligations or agreements made with the debtor. One technique for analyzing financial distress is the Discriminant Multivariate analysis. This multivariate statistical technique is used to predict and estimate the failure of a company known as the "Z-score Model." The Altman Z-score model uses 5 financial ratios as the best prediction for company failure. (Christian 2019).

$\mathrm{Z}=1.2(\mathrm{X} 1)+1.4(\mathrm{X} 2)+3.3(\mathrm{X} 3)+0.6(\mathrm{X} 4)+1.0(\mathrm{X} 5)$

Information:

$\mathrm{X} 1=$ working capital/total assets

$\mathrm{X} 2=$ retained earnings/total assets

$\mathrm{X} 3=$ operating profit/total assets

$\mathrm{X} 4=$ market value of equity/value of debt

$\mathrm{X} 5=$ sales/total assets

Variable relationship design to see how causality is between the independent variable and the dependent variable as well as the moderating variable, it is described as follows: 


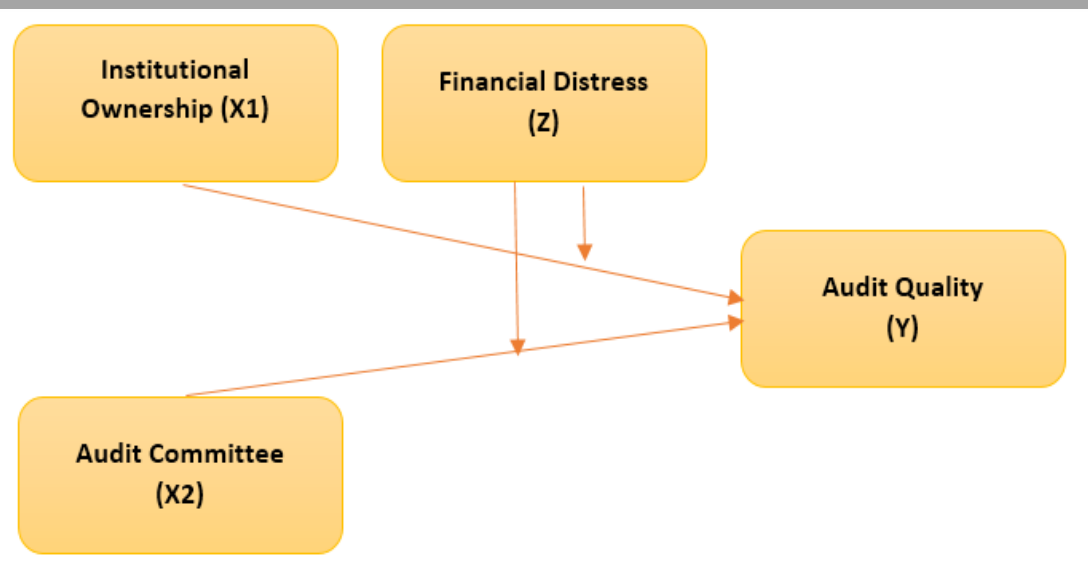

Figure 1. Variable Relationship Model

\section{Hypothesis Formulation} Quality

\section{The Effect of Institutional Ownership on Audit}

Institutional ownership describes the proportion of the number of shares owned by institutions within the company. Therefore, the existence of institutional parties will affect the audit results or audit quality of the company. Institutional investors have specific abilities in financial analysis, so they need quality information. Therefore, institutional investors place more emphasis on management about audit quality. Research conducted by Guizani \& Abdalkarim (2019) and Alhababsah (2019) shows that institutional ownership relates to audit quality. Furthermore, in Alzeaideen \& Al-Rawash's (2018) study, the results show that institutional ownership $\beta$ affects audit quality, but not significantly. The results in the two studies above are different from the research of Tanujaya \& Susiana (2021) and Johnbest \& Olghodo (2020), where Z institutional ownership does not affect audit quality.

\section{H1: Institutional ownership affects audit quality}

2. Influence of the Audit Committee on Audit Quality

The independence of the audit committee is considered capable of assuring the quality of the audit of financial statements. This also supports the view that the freedom of the audit committee is significant in ensuring the quality of the financial reporting process. As research conducted by Pertiwi \& Hardi (2016), Suryanto \& Thalassinos (2017), and Mustafa, Ahmed \& Chandren (2018) analysis results show that the audit committee hurts audit quality. Furthermore, in the research of Tanujaya and Susiana (2021) and Silviyani, Suratman \& Erlangga (2020), the analysis results show that the audit committee does not affect audit quality.

\section{H2: The Audit Committee does not affect Audit Quality}

\section{Effect of Financial Distress on Audit Quality}

Financial difficulties will affect companies that are threatened with bankruptcy to change auditors. Financial distress will indicate that the company's financial ability decreases to bear the audit fees charged by the auditors. It can lead to a break in the relationship between company managers and auditors. Jayanti \& Widhiyani (2014) in Elevandra \& Yunita (2021) found that financial distress hurts audit quality.
H3: Financial distress can moderate and strengthen institutional ownership of audit quality

H4: Financial distress can moderate but weaken the audit committee on audit quality

Research Methods

This research is quantitative, with a causal relationship analysis model to see how changes in the dependent variable are caused by the independent variable. The research model used to test the hypothesis is:

$A Q=\alpha+\beta I O W+\beta A C+\beta F D+e$

$\mathrm{AQ}=\alpha+\beta \mathrm{KI}+\beta \mathrm{KA}+\beta \mathrm{KI} * \mathrm{Z}+\beta \mathrm{KA} * \mathrm{Z}+\mathrm{e}$

$\mathrm{AQ}=$ audit quality

$\alpha=$ constant/intercept value

$\beta=$ direction of the regression coefficient

KI = institutional ownership

$=$ audit quality

$=$ financial distress

\section{Population and Sample}

The population in this study are manufacturing companies in the consumer goods sector listed on the Indonesia Stock Exchange in 2016-2020 and obtained from the website www.IDX.co.id

The sampling technique in this study was purposive sampling which was selected with specific considerations to produce data that followed the research objectives (Sugiyono, 2017). The criteria used in the sample are as follows:

a. Companies in the manufacturing sector that have been listed on the Indonesia Stock Exchange (IDX) in 2016-2020.

b. Companies that have complete and accessible financial reports for 2016-2020.

c. A company whose report presents all components in full according to the variables used.

Based on the research criteria obtained from purposive sampling calculations on manufacturing companies in the goods and consumption sector, a sample of 40 companies was obtained for 5 years. The number of observations was $\mathrm{N}=200$.

\section{Research Results and Discussion}

Model Feasibility Test

Overall Model Fit Test 
The statistical test is said to be good (fit) if there is a testing for equations 1 and 2 are, as shown in tables 2 and 3, as decrease in the value of $-2 \log$ Likelihood in the step 0 test to follows:

the next step in the second block. The results of the fit model

Table 1. Fit Test Results 1

Iteration History $\mathbf{a}, \mathbf{b}, \mathbf{c}$

\begin{tabular}{cccc}
\hline \multicolumn{2}{c}{ Iteration } & $\begin{array}{c}-2 \text { Log } \\
\text { likelihood }\end{array}$ & $\begin{array}{c}\text { Coefficients } \\
\text { Constant }\end{array}$ \\
\hline Step 0 & 1 & 269.996 & -.380 \\
& 2 & 269.995 & -.385 \\
& 3 & 269.995 & -.385 \\
\hline \multicolumn{2}{r}{ Source: SPSS output processed 2021 }
\end{tabular}

Table 2. Fit Test Results 2

Iteration History $\mathbf{a , b , c , d}$

\begin{tabular}{|c|c|c|c|c|c|}
\hline \multirow{2}{*}{ Iteration } & \multirow{2}{*}{-2 Log likelihood } & \multicolumn{4}{|c|}{ Coefficients } \\
\hline & & Constant & IOW & $\mathrm{AC}$ & FD \\
\hline \multirow[t]{4}{*}{ Step 1} & 237.908 & -3.002 & 2.192 & .150 & .621 \\
\hline & 236.449 & -3.643 & 2.736 & .150 & .796 \\
\hline & 236.433 & -3.715 & 2.801 & . 149 & .818 \\
\hline & 236.433 & -3.716 & 2.801 & . 149 & .818 \\
\hline
\end{tabular}

From the results of table 2, it shows that the initial -2 regression model is considered good (model fit) so that it can log-likelihood value is 269.996. After the two independent be used to predict audit quality. variables are entered, there is a change in the final -2 loglikelihood value to 236.433 . in table 3 , which means there is a The stage of testing equation 2 by including financial decrease in the value of -2 log-likelihood, which means the

Table 3. Fit Test Results 3

Iteration History a,b,c,d

\begin{tabular}{|c|c|c|c|c|c|c|c|c|}
\hline \multirow{3}{*}{\multicolumn{2}{|c|}{ Iteration }} & \multirow{3}{*}{$\begin{array}{c}-2 \log \\
\text { likelihood }\end{array}$} & \multicolumn{6}{|c|}{ Coefficients } \\
\hline & & & \multirow{3}{*}{$\begin{array}{r}\text { Constant } \\
-7.548\end{array}$} & \multirow{3}{*}{$\frac{\mathrm{IOW}}{-.491}$} & \multirow{3}{*}{$\frac{\mathrm{AC}}{2.289}$} & \multirow{3}{*}{$\frac{\mathrm{FD}}{6.091}$} & \multirow{3}{*}{$\frac{\mathrm{IOW}^{*} \mathrm{FD}}{2.569}$} & \multirow{3}{*}{$\begin{array}{l}\mathrm{AC}^{*} \\
\mathrm{FD} \\
-2.417\end{array}$} \\
\hline & & & & & & & & \\
\hline Step 1 & 1 & 220.443 & & & & & & \\
\hline & 2 & 214.916 & -13.369 & -.748 & 4.205 & 11.128 & 3.407 & -4.221 \\
\hline & 3 & 214.037 & -17.810 & -.811 & 5.682 & 15.122 & 3.568 & -5.572 \\
\hline & 4 & 213.970 & -19.542 & -.815 & 6.258 & 16.706 & 3.576 & -6.101 \\
\hline & 5 & 213.969 & -19.728 & -.815 & 6.320 & 16.878 & 3.576 & -6.158 \\
\hline & 6 & 213.969 & -19.730 & -.815 & 6.321 & 16.880 & 3.576 & -6.158 \\
\hline & 7 & 213.969 & -19.730 & -.815 & 6.321 & 16.880 & 3.576 & -6.158 \\
\hline
\end{tabular}

Source: SPSS output processed 2021

The test of equation 2 shows that the initial $-2 \log$ likelihood value is 269.996 by including the two independent variables and the moderating variable. The final -2 loglikelihood value becomes 213.969. which means that the regression model is considered good (model fit) so that it can be used to predict audit quality with moderating variables.

Regression Model Feasibility Test (Goodness of Fit Test)
Hosmer and Lemeshow's Goodness of Fit Test was used to assess the model used in the study whether it was suitable for use or not and fit the data. If the probability value (sig) $>0.05$, the model is considered acceptable because it matches the observation data and vice versa. The results of Hosmer and Lemeshow's Goodness of Fit Test in equation 1 are obtained as follows:

Table 4. Feasibility of Regression Model Hosmer and Lemeshow Test 1

\begin{tabular}{lccc}
\hline Step & Chi-square & df & Sig. \\
\hline 1 & 15.391 & 8 & .052 \\
\hline Hosmer and Lemeshow Test 2 & & \\
\hline Step & Chi-square & df & Sig. \\
\hline 1 & 5.884 & 8 & .660 \\
\hline \multicolumn{4}{l}{ Source: SPSS output processed 2021 }
\end{tabular}


The results of Hosmer and Lemeshow's Goodness of Goodness of Fit assumption to be accepted because it is Fit Test data processing in equation 1 obtained a significant following the observation data. value of 0.052 . and 0.660 . The significance value means 0.052 Coefficient of Determination Test (R2)

$>0.050$ and $0.660>0.05$, meaning that the model meets the

The results of Nagelkerke's R Square test in equations

Table 5. Model Summary Model Summary

\begin{tabular}{rccc}
\multicolumn{4}{c}{ Model Summary } \\
\hline Step & -2 Log & Cox \& Snell R & Nagelkerke R \\
likelihood & Square & Square \\
\hline 1 & $236.433^{\text {a }}$ & .154 & .209 \\
\hline
\end{tabular}

\begin{tabular}{cccc}
\multicolumn{4}{c}{ Model Summary } \\
\hline Step & $\begin{array}{c}-2 \text { Log } \\
\text { likelihood }\end{array}$ & $\begin{array}{c}\text { Cox \& Snell R } \\
\text { Square }\end{array}$ & $\begin{array}{c}\text { Nagelkerke R } \\
\text { Square }\end{array}$ \\
\hline 1 & $213.969^{\mathrm{a}}$ & .244 & .330 \\
\hline \multicolumn{4}{c}{ Source: SPSS output processed 2021 }
\end{tabular}

The results from the table above in equations 1 and 2 the financial distress variable as a moderating variable show the Nagelkerke R Square values of 0.209 and 0.330 , contributes to changes in audit quality.

which identify that the independent variable's ability to explain the audit quality variable before being moderated is $20.9 \%$. After being moderated, it rose to $33.0 \%$. This illustrates that

\section{Logistics Regression}

Logistic regression testing is intended to determine the direction of influence and changes in the coefficient value of each variable. The logistic regression test in equation 1 is:

Table 6. Logistic Regression Test Equation 1 Variables in the Equation

\begin{tabular}{llrrrrr}
\hline & \multicolumn{1}{c}{ B } & \multicolumn{1}{c}{ SE. } & Wald & Df & \multicolumn{1}{c}{ Sig. } \\
\hline Step 1 ${ }^{\mathrm{a}}$ & KI & 2.801 & .847 & 10.947 & 1 & .001 \\
& AC & .149 & .383 & .151 & 1 & .697 \\
& $\mathrm{Z}$ & .818 & .324 & 6.368 & 1 & .012 \\
& Constant & -3.716 & 1.266 & 8.622 & 1 & .003 \\
\hline \multicolumn{5}{c}{ Source: SPSS output processed 2021 }
\end{tabular}

The results of the logistic regression, namely the effect of institutional ownership and audit committee on audit quality, are as follows:

$A Q=-3,716+2,801 \mathrm{KI}+0,149 K A+0,818 \mathrm{Z}$

\section{Table 7. Logistic Regression Test Equation 2}

\begin{tabular}{|c|c|c|c|c|c|c|}
\hline \multicolumn{7}{|c|}{ Variables in the Equation } \\
\hline \multirow{6}{*}{ Step $1^{\mathrm{a}}$} & $\mathrm{K}$ & & $\begin{array}{l}\text { SE. } \\
1550\end{array}$ & Wald & df & Sig. \\
\hline & $\mathrm{AC}$ & 6.321 & 2.572 & 6.037 & 1 & 014 \\
\hline & FD & 16.880 & 7.339 & 5.290 & 1 & .021 \\
\hline & $\mathrm{KI} * \mathrm{Z}$ & 3.576 & 1.367 & 6.843 & 1 & .009 \\
\hline & $\mathrm{AC} * \mathrm{Z}$ & -6.158 & 2.424 & 6.454 & 1 & .011 \\
\hline & Constant & -19.730 & 7.781 & 6.429 & 1 & .011 \\
\hline
\end{tabular}

Source: SPSS output processed 2021

The results of the logistic regression test after being moderated are as follows.

$A Q=-19,730-0,815 I O W+6,321 A C+16,880 F D$ $+3,576 I O W * F D-6,158 A C * F D$

\section{Hypothesis testing}

Hypothesis testing is intended to determine the strength of the influence of the independent variable individually on the dependent variable by comparing the significance value at the 0.05 level. The results of hypothesis 


\author{
E-ISSN: 2469-6501 \\ VOL: 7, ISSUE: 10 \\ October/202 1 \\ DOI: http://dx.doi.org/10.33642/ijbass.v7n10p1 \\ https://creativecommons.org/licenses/by/4.0/
}

testing by looking at the significance value are as shown in Tables 6 and 7.

\section{The Effect of Institutional Ownership on Audit Quality}

The significance value for the institutional ownership variable $(\mathrm{KI})$ is 0.01 , which means < from 0.05 , so it can be concluded that the institutional ownership variable $(\mathrm{KI})$ has a significant effect on audit quality (AQ) thus hypothesis H1, which states institutional ownership has a significant impact on audit quality (AQ) is acceptable.

Institutional ownership reflects institutional investors who play an essential role in strengthening the corporate governance system. Based on the results of research by Alhababsah (2020), it can be interpreted that institutional investors are more likely to demand (or encourage management to demand) high-quality audits as an effective monitoring mechanism (bond). Level

high institutional ownership results in sufficient activism by shareholders and a strong capacity to implement and enforce corporate governance practices (Guizani \& Abdalkarim, 2019).

The results of this study are consistent with research by Alhababsah (2020), Guizani \& Abdalkarim (2019), which states that institutional ownership affects audit quality in a company. However, the results of this study contradict the research of Johnbest \& Olghodo (2020), Alzeaideen \& Rawash (2018), which also states that institutional ownership does not affect audit quality where institutional investors are ineffective in monitoring the reporting process.

\section{Influence of the Audit Committee on Audit Quality}

The results of the significance test of equation 1 in table 7 for the audit committee variable (KA) with a significance value of 0.697 , which means $>$ from the value of 0.05 so it can be concluded that the audit committee variable (KA) has no significant effect on audit quality. Thus hypothesis 2 , which states the audit committee has an impact on audit quality rejected. These results indicate that the audit committee has no significant effect on audit quality (AQ). The results of this study are consistent with the research of Tanujaya and Susiana (2021), Silviyani, Suratman \& Erlangga (2020), which state that the audit committee has no effect audit quality in a company. However, the results of this study contradict the research of Pertiwi \& Hardi (2016), Suryanto \& Thalassinos (2017), Mustafa, Ahmed \& Chandren (2018), which also state that the audit committee plays an essential part in the financial aspect of corporate governance because they guarantee audit quality while at the same time securing investor enthusiasm.

\section{The Effect of Financial Distress Moderates the Effect of Institutional Ownership on Audit Quality}

For the variable of institutional ownership (KI), after being moderated by the financial distress variable $(Z)$, it is known that the significance value is 0.009 (table 8), which means < from 0.05 , so it can be concluded that the variable of institutional ownership after being moderated $\left(\mathrm{KI}^{*} \mathrm{Z}\right)$ has a significant effect on the quality audit (AQ) thus hypothesis $\mathrm{H} 3$ which states that Financial Distress can moderate the impact of institutional ownership on audit quality is accepted. Institutional ownership reflects institutional investors who play an essential role in strengthening the corporate governance system with a practical part and monitoring (Yunas, Uddin \& Khan, 2020). Institutional investors are more likely to demand (or encourage management to demand) high-quality audits as effective monitoring (bonding) mechanism (Alhababsah, 2020).

\section{The Effect of Financial Distress Moderates the} Effect of the Audit Committee on Audit Quality

The results of the significance test of equation 2 for the audit committee variable after being moderated by the financial distress variable with a significance value of 0.011 which means < from the value of 0.05 so it can be concluded that the audit committee variable after being moderated by the financial distress variable $\left(\mathrm{AC}^{*} \mathrm{Z}\right)$ has a significant effect on quality. Thus, hypothesis H4, which states that Financial Distress moderates the impact of the audit committee on audit quality, is accepted.

The competence of the audit committee allows the audit committee to control matters relating to the company's finances from an early age so that the audit committee can make corrections to the company's financial condition to avoid the company from financial difficulties. Some companies only list their names on the audit committee but do not maximize their duties on the audit committee. (Dirman, 2020). Companies with competent audit committees rarely choose sizeable public accounting firms because they already have an audit committee that assists external auditors in the monitoring process. (Tanujaya \& Susiana, 2021).

\section{Conclusion}

This study aims to analyze the effect of institutional ownership and audit committee on audit quality with financial distress as moderation by taking research samples from manufacturing companies in the consumer goods and industrial sector listed on the Indonesia Stock Exchange for 2016 - 2020 Based on the results of the analysis, conclusions can be drawn, as follows:

1. Institutional ownership has a positive and significant effect on audit quality. This illustrates that institutional ownership in the company can pressure the management to encourage the quality of the audit produced. Besides that, its supervisory function can be said to run effectively.

2. The audit committee has no significant effect on audit quality. This means that the number of audit committees in the company is not a good reason for the quality of the audit. This also illustrates that the competence of the audit committee is much more important in the company than the number.

3. Financial distress can moderate and strengthen the influence of institutional ownership on audit quality. 


\author{
E-ISSN: 2469-6501 \\ VOL: 7, ISSUE: 10 \\ October/2021 \\ DOI: http://dx.doi.org/10.33642/ijbass.v7n10p1 \\ (c) (†) \\ https://creativecommons.org/licenses/by/4.0/
}

This indicates that the company's financial health condition plays a role in producing a quality audit. Companies with poor financial health will encourage institutional shareholders to increase their supervision so that audit results will be good.
4. Financial distress can moderate the influence of the audit committee on audit quality with an opposing direction of effect, which means that if the company experiences financial distress, it will encourage the audit committee to influence audit quality.

\title{
References
}

Abdalkrim, M. G. (2019). Ownership structure and audit quality: the mediating effect of board independence. Emerald Publishing.

Agoes, S. (2017). Petunjuk Praktis Pemeriksaan Akuntan oleh Akuntan Publik, Buku 1, Edisi 5. Jakarta: Salemba empat.

Alhababsah, S. (2019). Ownership structure and audit quality: An empirical analysis considering ownership types in Jordan. Journal of International Accounting, Auditing, and Taxation, 71-84.

Aree Saeed Mustafa, A. C.-A. (2018). Board diversity, audit committee characteristics and audit quality: The moderating role of the control-ownership wedge. Business and Economic Horizons, 587-614.

Arens A. Alvin, R. J. (2015). Auditing dan Jasa Assurance Pendeketan Terintegrasi. Jakarta: Jilid 1 Edisi Lima Belas, Erlangga. Bursa Efek Indonesia. (n.d.). Retrieved from www.idx.co.id

Dede Elevendra, N. H. (2021). Pengaruh Audit Tenure dan Auditor Switching terhadap Kualitas Audit dengan Financial Distress sebagai Pemoderasi. Jurnal Eksplorasi Akuntansi, 82-97.

Dirman, A. (2020). FINANCIAL DISTRESS: THE IMPACT OF INSTITUTIONAL OWNERSHIP. International Journal of Management Studies and Social Science Research, 202-210.

Hamdani, S. M. (2016). Good corporate governance: tinjauan etika dalam praktik bisnis.

Husnin, A. I. (2016). Corporate governance structure and its relationship with audit fee-evidence. Asian Social Science, $305-$ 317.

I, G. (2018). Aplikasi Analisis Multivariate Dengan Program SPSS. Universitas Diponegoro.

Khaled Abdulwahab Alzeaideen1, S. Z.-R. (2018). The Effect of Ownership Structure and Corporate Debt on Audit Quality: Evidence From Jordan. International Journal of Economics and Financial Issues, 51-58.

Kristanti, F. (2019). Financial Distress Teori dan Perkembangannya Dalam Konteks Indonesia. Malang: Intelegensi Media.

Lestari, D. M. (2019). Pengaruh Due Professional Care dan Kompetensi Auditor Terhadap Kualitas Audit. Jurnal Riset Akuntansi dan Keuangan, 319-326.

Mei Yuniati, K. R. (2016). Pengaruh kebijakan Deviden,. Journal of Accounting. Vol.2, No.2.

Melani, A. (2017, Februari 14). EY Indonesia Kena Denda, Ini Penjelasan Indosat. Retrieved from Liputan6.com: https://www.liputan6.com/saham/read/2855707/ey-indonesia-kena-denda-ini-penjelasan-indosat

Mirri Y Pasaribu, T. d. (2016). Pengaruh Struktur. Jurnal Administrasi Bisnis. Vol. 35, No. 1. 154-164., 154-164.

Montserrat Manzaneque*, A. M. (2016). Corporate governance effect on financial distress likelihood:. Revista De Contabilidad - Spanish Accounting Review 19 (1) (2016) 111-121, 111-121.

Mulyadi. (2016). Sistem Akuntansi. Jakarta: Salemba Empat.

Nastia Putri Pertiwi, A. H. (2016). Pengaruh Masa Perikatan Audit, Spesialisasi Industri Kap, Reputasi Kap Dan Komite Audit Terhadap Kualitas Audit (Studi Empiris Perusahaan Manufaktur Di Bei Tahun 2011-2014). Jurnal Akuntansi, 147-160.

Nouman Younas, S. U. (2020). Corporate governance and financial distress: Asian emerging market perspective. Emerald Publishing.

OJK, P. (2015). Pasal 1 Ayat 1 Peraturan OJK 55/2015.

Ologhodo, J. a. (2020). Effect Of Ownership Structure On Audit Quality Of Listed Conglomerate Companies In Nigeria. International Journal Of Advanced Research (Ijar), 1165-1177.

P., S. M. (2016). Pengaruh Kebijakan Hutang, Kepemilikan Manajerial,. Jurnal Ilmu manajemen. Vol. 21, No. 2.

Sekaran, U. d. (2017). Metode Penelitian untuk Bisnis: Penelitian Pengembangan-Keahlian, Edisi 6, Buku 2. Jakarta: Salemba Empat.

Stephanie Yolanda, F. I. (2019). Pengaruh Audit Tenure, Komite Audit Dan Audit Capacity Stress Terhadap Kualitas Audit. Jurnal Eksplorasi Akuntasi, 543-555.

Sugiyono. (2017). Metode Penelitian Kuantitatif Kualitatif dan R\&D. Bandung: Alfabeta. 
Susiana, K. T. (2021). Struktur Kepemilikan Dan Karakteristik Dewan Perusahaan Terhadap Kualitas Audit Di Indonesia. Global Financial Accounting Journal, 58-74.

T. Suryanto, J. T. (2017). Board Characteristics, Audit Committee, and Audit Quality: The Case Of Indonesia. International Journal of Economics and Business Administration, 44-57.

Wardana, M. A. (2016). Pengaruh Gaya Kepemilikan Tranformasional, Obyektivitas, Integritas dan Etika Auditor Terhadap Kualitas Audit. E-Jurnal Akuntansi, 948-976.

Yuli Anita Silviyani, A. S. (2020). Pengaruh Tenure Audit, Kepemilikan Asing dan Komite Audit Terhadap Kualitas Audit dengan Moderasi Reputasi KAP. Prosiding Konferensi Nasional Ekonomi Manajemen dan Akuntansi (KNEMA). 